\title{
Malignant transformation arising in mature cystic teratoma
}

\author{
Sherpa $\mathrm{P}^{1}$, Baral $\mathrm{R}^{1}$, Kansakar TK ${ }^{1}$ \\ ${ }^{1}$ Departmant of Pathology, Patan Academy of Health Sciences, Lalitpur, Nepal
}

\author{
Keywords: \\ Malignant transformation; \\ Squamous cell carcinoma; \\ Teratoma
}

\begin{abstract}
Background: The prognosis of patients with malignant transformation arising within mature cystic teratoma is poor. However, preoperative diagnosis is difficult due to its rarity. The aim of this study was to evaluate the clinical and histopathological characteristics of such malignancies.

Materials and Methods: A retrospective cross sectional study on a series of cases was performed in the Department of Pathology, Patan Academy of Health Sciences, Patan Hospital, Lalitpur, Nepal from April 2011 to March 2016. Data from the histopathology database were analyzed using SPSS version 16.0.

Results: Mature cystic teratoma comprised 230 cases (57.6\%) out of total 399 cases of ovarian neoplasms. Malignant transformation was noted in $7(3 \%)$ of the mature cystic teratoma. The mean age at diagnosis of patients with malignant transformation of mature cystic teratoma was 47.57 years. The size of the tumors ranged from $7-14 \mathrm{~cm}$. The mean diameter of tumor was $10.28 \mathrm{~cm}$. There was significant difference in age between mature cystic teratoma and malignant transformations arising within mature cystic teratoma. No significant association was noted in tumor size. Torsion was noted in a single case. Squamous cell carcinoma was the most common malignant tumor seen in 5 cases. The TNM stage distribution was T1aNx for 4 cases, T2aNx for one case and T3aNx for 2 cases.
\end{abstract}

Conclusion: Squamous cell carcinoma is the most common malignancy arising in mature cystic teratoma. Advanced age is a significant risk factor for malignant transformation in mature cystic teratoma.

\section{INTRODUCTION}

Mature cystic teratoma (MCT), commonly known as dermoid cyst is the most common benign tumor of the ovary. It is originated from primordial germ cells and histologically composed of three well differentiated elements, namely ectoderm, mesoderm and endoderm. ${ }^{1,2}$

\author{
Correspondence: \\ Dr. Palzum Sherpa, MBBS, MD \\ Lecturer, Department of Pathology, Patan Academy of Health Sciences, \\ Lalitpur, Nepal, \\ E-mail:palzumsherpa@pahs.edu.np
}

Malignant transformation of MCT is an uncommon complication occurring in approximately $0.17-2 \%$ of all cases and the most often reported malignancy is squamous cell carcinoma. ${ }^{3}$

The current study aims to evaluate the prevalence, age distribution, menopausal status, size of tumor, laterality, presence of torsion, histopathological diagnosis, organ involved and TNM staging in patients diagnosed with a malignant transformation arising within MCT at Patan Academy of Health Sciences over a 5 year study period. 
Table 1: Summary of cases showing malignant transformation in MCT

\begin{tabular}{cccccccccc}
\hline Cases & $\begin{array}{c}\text { Age } \\
(\mathbf{y r s})\end{array}$ & Menopause & Primary surgery & $\begin{array}{c}\text { Maximum tumor } \\
\text { dimension }(\mathbf{c m})\end{array}$ & Torsion & Diagnosis & $\begin{array}{c}\text { Organ (s) } \\
\text { involved }\end{array}$ & Stage (TNM) \\
\hline 1 & 62 & Yes & TAH with BSO & 10 & Absent & $\begin{array}{c}\text { Squamous cell } \\
\text { carcinoma }\end{array}$ & $\begin{array}{c}\text { Left ovary and } \\
\text { omentum }\end{array}$ & T3aNx \\
\hline 2 & 35 & No & $\begin{array}{c}\text { Salpingo- } \\
\text { oophorectomy }\end{array}$ & 9 & Present & $\begin{array}{c}\text { Squamous cell } \\
\text { carcinoma }\end{array}$ & Ovary & T1aNx \\
\hline 3 & 70 & Yes & TAH with BSO & 14 & Absent & Adenocarcinoma & Left ovary & T1aNx \\
\hline 4 & 40 & No & TAH with BSO & 7 & Absent & $\begin{array}{c}\text { Squamous cell } \\
\text { carcinoma }\end{array}$ & Right ovary & T1aNx \\
\hline 5 & 47 & No & TAH with BSO & 8 & Absent & $\begin{array}{c}\text { Squamous cell } \\
\text { carcinoma }\end{array}$ & $\begin{array}{c}\text { Right ovary and } \\
\text { cervix }\end{array}$ & T2aNx \\
\hline 6 & 50 & No & TAH with BSO & 12 & Absent & Carcinoid tumor & Left ovary & T1aNx \\
\hline 7 & 30 & Yes & $\begin{array}{c}\text { Salpingo- } \\
\text { oophorectomy }\end{array}$ & 12 & Absent & $\begin{array}{c}\text { Squamous cell } \\
\text { carcinoma }\end{array}$ & $\begin{array}{c}\text { Ovary, } \\
\text { fallopiand omentum }\end{array}$ \\
\hline
\end{tabular}

Table 2: Comparison of clinical characteristics of patients with MCT and malignant transformation arising within MCT

\begin{tabular}{cccccc}
\hline & $\begin{array}{c}\text { MCT } \\
\text { Mean } \pm \text { SD }\end{array}$ & $\begin{array}{c}\text { MCT with malignant } \\
\text { transformation } \\
\text { Mean } \pm \text { SD }\end{array}$ & Mean difference & Lower & U5\% confidence interval \\
\cline { 3 - 6 } Age (yrs) & $32.59 \pm 11.9$ & $47.57 \pm 14.59$ & 14.98 & 5.90 & 24.05 \\
\hline $\begin{array}{c}\text { Tumor size } \\
(\mathbf{c m})\end{array}$ & $8.2 \pm 3.53$ & $10.28 \pm 2.49$ & 2.08 & -0.57 & 4.74 \\
\hline
\end{tabular}

\section{MATERIALS AND METHODS}

This is a retrospective cross sectional study performed in the Department of Pathology at Patan Academy of Health Sciences, Patan Hospital, Lalitpur, Nepal. Ethical clearance was obtained from institutional review committee. This study was conducted in the histopathology samples received from April 2011 to March 2016. The variables entered in the database were histopathology number, patient identity number, name, age, menopausal status, surgery undertaken, histopathological diagnoses, size of the tumor, laterality, presence or absence of torsion, organ involved and TNM staging. Data were analysed using SPSS version 16.0.

\section{RESULTS}

Mature cystic teratoma comprised 230 cases $(57.6 \%)$ out of total 399 cases of ovarian neoplasms. Malignant transformation was noted in $7(3 \%)$ of the MCT. The clinical and pathological details of all the 7 cases are tabulated. (Table. 1) The mean age at diagnosis of patients with malignant transformation of MCT was 47.57 years (range, 30 to 70 years), which was higher than that of patients with benign teratomas who had a mean age of 32.59 years. A statistically significant difference was noted in age ( $\mathrm{p}$ value: 0.001 ) between MCT and malignant transformation arising within mature cystic teratoma. Three of the patients were postmenopausal. The size of the tumors with malignant transformation ranged from $7-14 \mathrm{~cm}$. The mean diameter of tumor was $10.28 \mathrm{~cm}$ in the malignancy group which was larger compared to $8.2 \mathrm{~cm}$ of the benign group. The statistical association regarding tumor size between MCT and malignant transformation arising with MCT was not significant ( $\mathrm{p}$ value: 0.124$)$. (Table. 2 )

Ischemic modifications, presumably due to torsion, was noted in a single case. Malignant change was noted in left sided ovary in three cases, right sided in two cases and in two patients side was not mentioned. In case 1 and 5, MCT was present in bilateral ovaries. However, malignant transformation was noted in only one ovary, left and right respectively.

Squamous cell carcinoma was the most common malignant tumor seen in 5 cases. (fig. 1) Histologically, two cases of these were well differentiated and three were moderately differentiated. There was one case each of adenocarcinoma and carcinoid tumor. (fig.2 and 3) Lymphovascular invasion was noted in case 2 and 5. The TNM stage distribution was as follows: 4 were T1aNx, 1 was T2aNx and 2 were T3aNx.

\section{DISCUSSION}

Mature cystic teratoma was the most prevalent tumor 


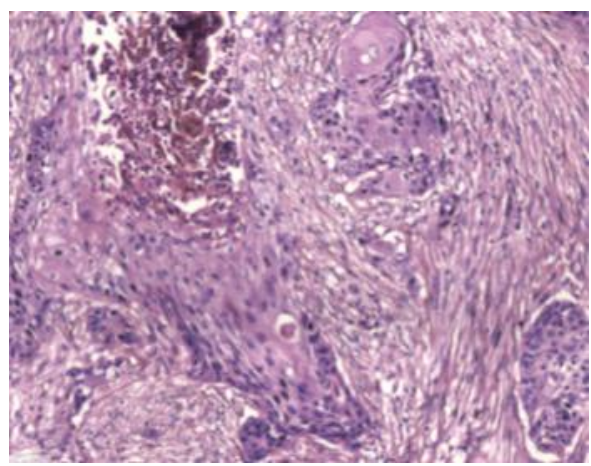

Figure 1: Photomicrograph showing squamous cell carcinoma with islands of malignant squamous cells (H\&E stain, X40).

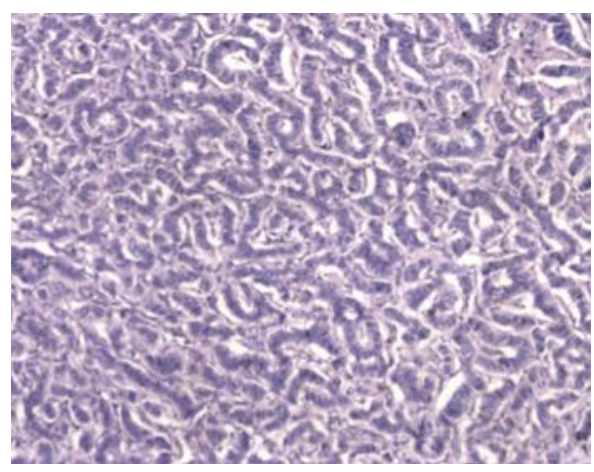

Figure 3: Photomicrograph showing carcinoid tumor (H\&E stain, X40).

accounting for $230(57.6 \%)$ out of total 399 cases in this study. In the present study, malignant transformation was noted in $7(3 \%)$ of the MCT corroborating data from various studies. ${ }^{4,5}$ The prognosis of patients with malignant transformation arising within MCT is poor. There are no particular symptoms or signs which are characteristic of malignancy arising in a dermoid cyst. Pre-operative diagnosis of malignant transformation within MCT is extremely challenging but is of utmost significance for optimal treatment planning. The malignant component may exist only focally. Hence, careful gross examination and adequate sampling is essential.

The mean age at diagnosis of patients with malignant transformation of MCT was higher than that of patients with benign teratomas. Similar findings indicating that malignant transformation increases with age was reported in studies conducted by Kikkawa et al, Bal et al and Dos Santos et al. ${ }^{6-8}$

In the present study, mean diameter of tumor was larger in malignancy group compared to the benign group. However, the association was not statistically significant ( $p$ value: 0.124 ). In contrast, a study by Kikkawa et al, showed a significant association in tumor size with $\mathrm{p}$ value $<0.0001$

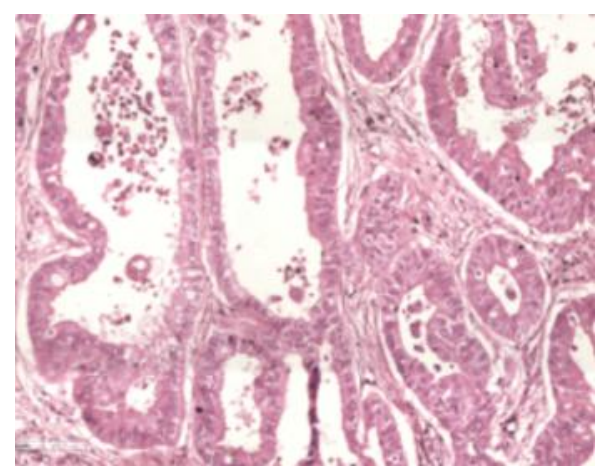

Figure 2: Photomicrograph showing adenocarcinoma. The tumor cells are arragned in glandular pattern. (H\&E stain, X40).

and concluded that a tumor diameter larger than $9.9 \mathrm{~cm}$ had $86 \%$ sensitivity for malignancy. ${ }^{6}$ It is recommended that a diameter equal to or greater than $10 \mathrm{~cm}$ or a tumor arising in MCT demonstrating rapid growth should prompt suspicion. ${ }^{8}$

Squamous cell carcinoma was the most common malignant tumor seen in 5 cases, supporting previous findings reported in many literatures. ${ }^{9-11}$ Carcinomas can arise from any of the mature epithelial tissue present. Apart from squamous cell carcinoma, other epithelial malignancies reported in MCT are basal cell carcinoma, sebaceous carcinoma, adenocarcinoma and neuroendocrine tumor. ${ }^{5}$ In our study, one case each of adenocarcinoma and carcinoid tumor was present. Better prognosis has been reported when the malignant element is a squamous cell carcinoma compared with adenocarcinoma or sarcoma. ${ }^{12}$

The prognosis for these tumors has been often reported to be very poor with a five-year survival rate of only 15 $30 \% \cdot{ }^{13}$ Factors such as cyst wall invasion, rupture, adhesion, vascular invasion and higher stage carry an unfavorable prognosis. Certain serum markers like squamous cell carcinoma (SCC) antigen and carcinoembryonic antigen (CEA) are elevated in squamous cell carcinoma arising in MCT. ${ }^{6,7}$ Early detection and complete surgical resection are important for long term survival of the patients. ${ }^{14}$

\section{CONCLUSION}

Squamous cell carcinoma is the most common malignancy arising in MCT. Advanced age is significant risk factor for malignant transformation in MCT.

\section{REFERENCES}

1. Peterson WF, Prevost EC, Edmunds FT, Hundley JM, Jr., Morris FK. Benign cystic teratomas of the ovary; a clinico-statistical study of 1,007 cases with a review of the literature. Am J Obstet Gynecol . 1955;70:368-82. Crossref

2. Matz MH. Benign cystic teratomas of the ovary. A review. Obstet 
Gynecol Surv. 1961;16:591-605. Crossref

3. Mandal S, Dhingra K, Gupta P, Khurana N. Rare growth of a psammomatous meningioma in a mature ovarian teratoma: a case report. Pathol Res Pract. 2010;206:322-4. Crossref

4. Black JD, Roque DM, Pasternak MC, et al. A series of malignant ovarian cancers arising from within a mature cystic teratoma: a single institution experience. Int J Gynecol Cancer. 2015;25:792-7. Crossref

5. Ulker V, Gedikbasi A, Numanoglu C, et al. Mucinous adenocarcinoma arising in ovarian mature cystic teratoma in pregnancy. Arch Gynecol Obstet. 2009;280:287-91. Crossref

6. Kikkawa F, Nawa A, Tamakoshi K, et al. Diagnosis of squamous cell carcinoma arising from mature cystic teratoma of the ovary. Cancer. 1998;82:2249-55. Crossref

7. Bal A, Mohan H, Singh SB, Sehgal A. Malignant transformation in mature cystic teratoma of the ovary: report of five cases and review of the literature. Arch Gynecol Obstet. 2007;275:179-82. Crossref

8. Dos Santos L, Mok E, Iasonos A, et al. Squamous cell carcinoma arising in mature cystic teratoma of the ovary: a case series and review of the literature. Gynecol. Oncol. 2007;105:321-4. Crossref
9. Koc S, Tapisiz OL, Turan T, et al. Malignant transformation of mature cystic teratoma of the ovary: a case series. J Exp Ther Oncol. 2015;11:11-6. Crossref

10. Kalampokas E, Boutas I, Kairi-Vasilatou E,et al. A rare case report of squamous-cell carcinoma arising from mature cystic teratoma of ovary. Il Giornale di chirurgia. 2014;35:241-5. Crossref

11. Rim SY, Kim SM, Choi HS. Malignant transformation of ovarian mature cystic teratoma. Int J Gynecol Cancer. 2006;16:140-4. Crossref

12. Tseng CJ, Chou HH, Huang KG, et al. Squamous cell carcinoma arising in mature cystic teratoma of the ovary. Gynecol oncol. 1996;63:364-70. Crossref

13. Curling OM, Potsides PN, Hudson CN. Malignant change in benign cystic teratoma of the ovary. Br J Obstet Gynaecol. 1979;86:399-402. Crossref

14. Park JY, Kim DY, Kim JH, Kim YM, Kim YT, Nam JH. Malignant transformation of mature cystic teratoma of the ovary: experience at a single institution. Eur J Obstet Gynecol Reproduct Biol. 2008;141:173-8. Crossref 